UDC 616-056.52-053.2

Y.M. Nechytaylo, N.I. Kovtyuk

\title{
OVERWEIGHT AND OBESITY IN SCHOOL-AGE CHILDREN
}

Higher State Educational Institution of Ukraine "Bukovinian State Medical University (Chernivtsi)

\begin{abstract}
Childhood obesity has become a global public health problem. This paper describes the current prevalence of school-age children obesity in Chernivtsi region. We examined 848 children (mean age $-13,9 \pm 0,06$ years) from different parts of the region. Body mass index (BMI) and waist-to-hip index were calculated, Z-index of BMI was estimated according to the local anthropometric percentiles standards. The prevalence of total overweight was $19,9 \%$ including $13,6 \%$ of obesity. The prevalence also varies by age, gender and place of living. In boys over-
\end{abstract}

Background. Overweight and obesity among adult and children remain as public health problems all over the world $[6,7]$. In the past three decades, child overweight and obesity prevalence has risen substantially in most high-income countries and, from the scarce data available, seems to be rising rapidly in low-income and middle-income countries $[4,5]$. Excess of body weight in childhood is associated with overweight in adulthood and higher risk of different diseases, disability and premature death. Childhood obesity increases general morbidity and mortality and its effects on cardiovascular risk factors in adulthood are substantial. There are also obesity-related diseases such as metabolic syndrome, diabetes mellitus second type, arterial hypertension and other cardiovascular disease $[1,6]$. The World Health Organization classifies adult individuals as overweight if their body mass index (BMI) exceeds $25 \mathrm{~kg} / \mathrm{m}^{2}$ and obese if BMI exceeds $30 \mathrm{~kg} / \mathrm{m}^{2}$. With this classification the prevalence of obesity in the United States and Europe has been $20 \%$ and even more [7]. These levels of obesity targeted education, prevention, and early detection programs for those persons at the greatest risk. Nutritive and metabolic determinants, lifestyle choices and genetic predispositions are major factors contributing to obesity [3, 4]. The difference between adult and children overweight detection has methodical issues. The detection of children overweight is generally based on levels of weight adjusted for height in relation to national gender and age percentile standard. For early childhood simple weight-for-height proportion is used but for school-age children BMI is more suitable. The overweight is estimated with the level of BMI value over $90 \%$ and obesity in cases with level over $95 \%$ [6]. In Ukraine the prevalence of overweight and obesity in school-age children in recent years has not been studied thoroughly. Overweight and obesity, as well as their related diseases, are largely preventable. Prevention of childhood obesity therefore needs high priority.

Objective: The aim of this study was to determine the prevalence of obesity among school-age children living in Chernivtsi region.

Materials and methods. In total 848 children in age 10-17 years (mean age - 13,9 $\pm 0,06$ years, weight was in $20,8 \%$ and $19,2 \%$ - in girls, obesity $14,6 \%$ and $12,3 \%$ respectively. The prevalence of obesity is the highest in age 12 and 13 years - more than $20 \%$. The overweight in our children has positive correlation with higher systolic blood pressure $(\mathrm{r}=0,27, \mathrm{p}<0,05)$ and negative with physical performance $(\mathrm{r}=-0,21, \mathrm{p}<0,05)$.

Key words: school-age children, body mass index, overweight, obesity

$45,4 \%$ boys and $54,6 \%$ girls) from urban and rural areas of region were examined in schools during screening for elevated blood pressure. The study includes assessment of resting anthropometric data, physical activity habits, blood pressure, structure and quality of nutrition, food preferences, family and socioeconomic data. The anthropometric measurements and pubertal assessments were carried out on all children. Body weight was measured in kilograms (to one decimal point) using a digital balance and height was measured to the nearest $1 \mathrm{~cm}$ using a stadiometer. Waist and hip circumference were measured in a standing position in centimeters using an inelastic tape. BMI and waist-to-hip index were calculated, according to local anthropometric percentiles standards Z-index of BMI was estimated. Unlike in adults, BMI cut-off points used to classify overweight and obesity in children should be sexage-specific. Overweight and obesity were defined as BMI over the $90^{\text {th }}\left(Z\right.$-index $>2$ ) and $95^{\text {th }}$ percentile (Z-index $>3$ ) respectively. Pubertal assessment in children was obtained using the Tanner 5-point pubertal self-rating scale. Statistical analysis was conducted with program Statistica (version 5.11, StatSoft Inc.). Data were expressed as mean \pm standard error for quantitative variables and as numbers and percentages for categorical variables. Statistical analysis was performed using the Student's t-test for numerical variables. All p-values were two-tailed and $p<0,05$ was considered statistically significant.

Results of the research and their discussion. Anthropometric measurements were taken at each research age group and were standardized using procedures Z-index assessment for BMI. In total cohort Z-index of BMI was slightly higher 0-point $0,43 \pm 0,05$. There were no significant difference between boys and girls - Z-index BMI in boys $0,37 \pm 0,08$ and in girls $-0,48 \pm 0,06(p>0,05)$. The prevalence of total overweight was $19,9 \%$ including $13,6 \%$ of obesity. In boys overweight was $20,8 \%$ and $19,2 \%$ - in girls, obesity accordingly - 14,6\% and $12,3 \%$. For comparison recent studies by WHO indicate that approximately $20 \%$ of school agechildren in European countries are overweight and $5 \%$ are obese [7]. In our research level of obesity 
was nearly triple higher. The gender distribution of BMI Z-index was shown on figure 1. There were difference between children body mass dependent on place of living: Z-index of rural students was twice higher $(0,70 \pm 0,10)$ in comparison with urban $(0,34 \pm 0,06, p<0,05)$ and prevalence of overweight also differed $-24,6 \%$ and $18,2 \%$ accordingly.

The dynamic of anthropometric measurements and indexes in our research was shown in the table. The body mass and the chest circumference were arising gradually with linear dependence to age. Both indexes were nearly the same in all age subgroups. The BMI level and the waist-to-hip index were changed with the age in opposite direction but positively correlate with overweight.

The body mass and chest circumference differed non-significantly in non-overweight and overweight children. The difference of data was significant in BMI - $(18,9 \pm 0,08) \mathrm{kg} / \mathrm{m}^{2}$ versus $(25,5 \pm 0,27)$ $\mathrm{kg} / \mathrm{m}^{2}$, in Z-index of BMI - $-0,13 \pm 0,04$ versus $2,67 \pm 0,04$ and in waist-to-hip index $-0,77 \pm 0,003$ versus $0,81 \pm 0,005$. All these indexes after adjusting for age had diagnostic values for obese children too and could be used for diagnostic of overweight and obesity in different age group.

We also analyzed the prevalence of overweight and obesity in children for age groups between 10 and 17 years (fig. 2). The highest prevalence of obe- sity was in 12 and 13 years - more than $20 \%$ $(20,7 \%$ and $21,3 \%)$. The decrease in next age period correlated with puberty stage $(\mathrm{r}=-0,14, \mathrm{p}<0,05)$ and pubertal stature growth acceleration $(\mathrm{r}=-0,21$, $\mathrm{p}<0,05)$. The velocity of the stature increment exceeds the rate of increase in the body mass. Our data differ from results obtained in our region by other pediatrician where the changes were linear in nature [2]. By our opinion the difference depends mostly on inequality of the research design.

Although current understanding of the health consequences of overweight is predominately based on adult studies, increasing evidence suggests that childhood obesity has a number of not only immediate but long-term health programming consequences. Overweight and obese children are likely to maintain their status in adulthood and will be at higher risks for developing chronic diseases such as hypertension, heart disease and certain other problems. The overweight in our children also has positive correlation with systolic blood pressure $(r=0,27, p<0,05)$ and negative with physical performance $(\mathrm{r}=-0,21$, $\mathrm{p}<0,05)$.

In conclusion, childhood obesity is a serious public threat in many countries worldwide including Ukraine. Obesity has many health and financial consequences to individuals, their families and society in general and is largely preventable. Therefore, diag-

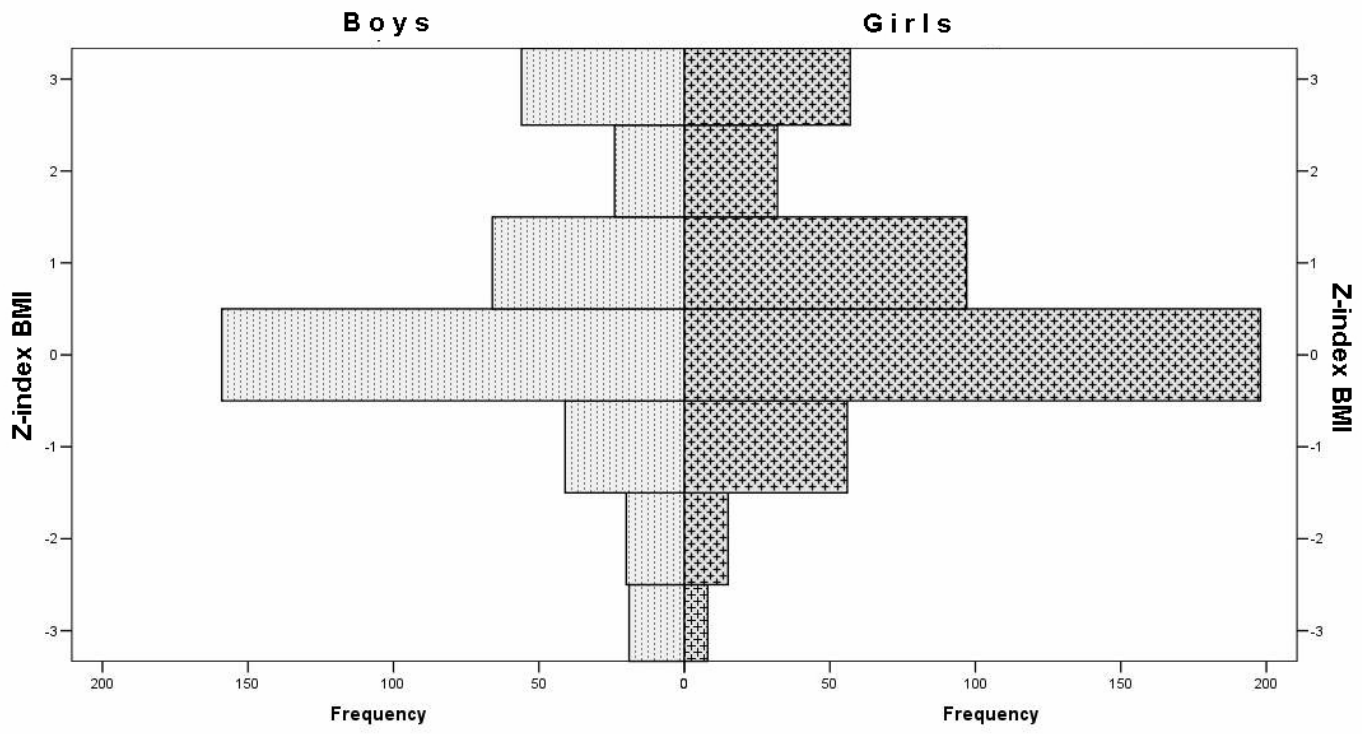

Fig.1. Children distribution by Z-index of BMI according to gender

Table

Anthropometric data and indexes in different age group

\begin{tabular}{|c|c|c|c|c|c|c|c|c|}
\hline \multirow{2}{*}{ Index } & \multicolumn{9}{|c|}{ Age of children } \\
\cline { 2 - 9 } & 10 & 11 & 12 & 13 & 14 & 15 & 16 & 17 \\
\hline Body mass, $\mathrm{kg}$ & 34,5 & 41,0 & 47,4 & 50,5 & 56,9 & 58,6 & 59,7 & 61,9 \\
\hline Chest circumference, cm & 67,1 & 72,8 & 77,6 & 79,6 & 82,6 & 83,7 & 85,4 & 87,9 \\
\hline BMI, $\mathrm{kg} / \mathrm{m}^{2}$ & 17,3 & 18,7 & 19,9 & 20,0 & 20,5 & 20,6 & 20,7 & 21,9 \\
\hline Waist-to-hip index & 0,83 & 0,82 & 0,80 & 0,78 & 0,79 & 0,76 & 0,76 & 0,75 \\
\hline
\end{tabular}




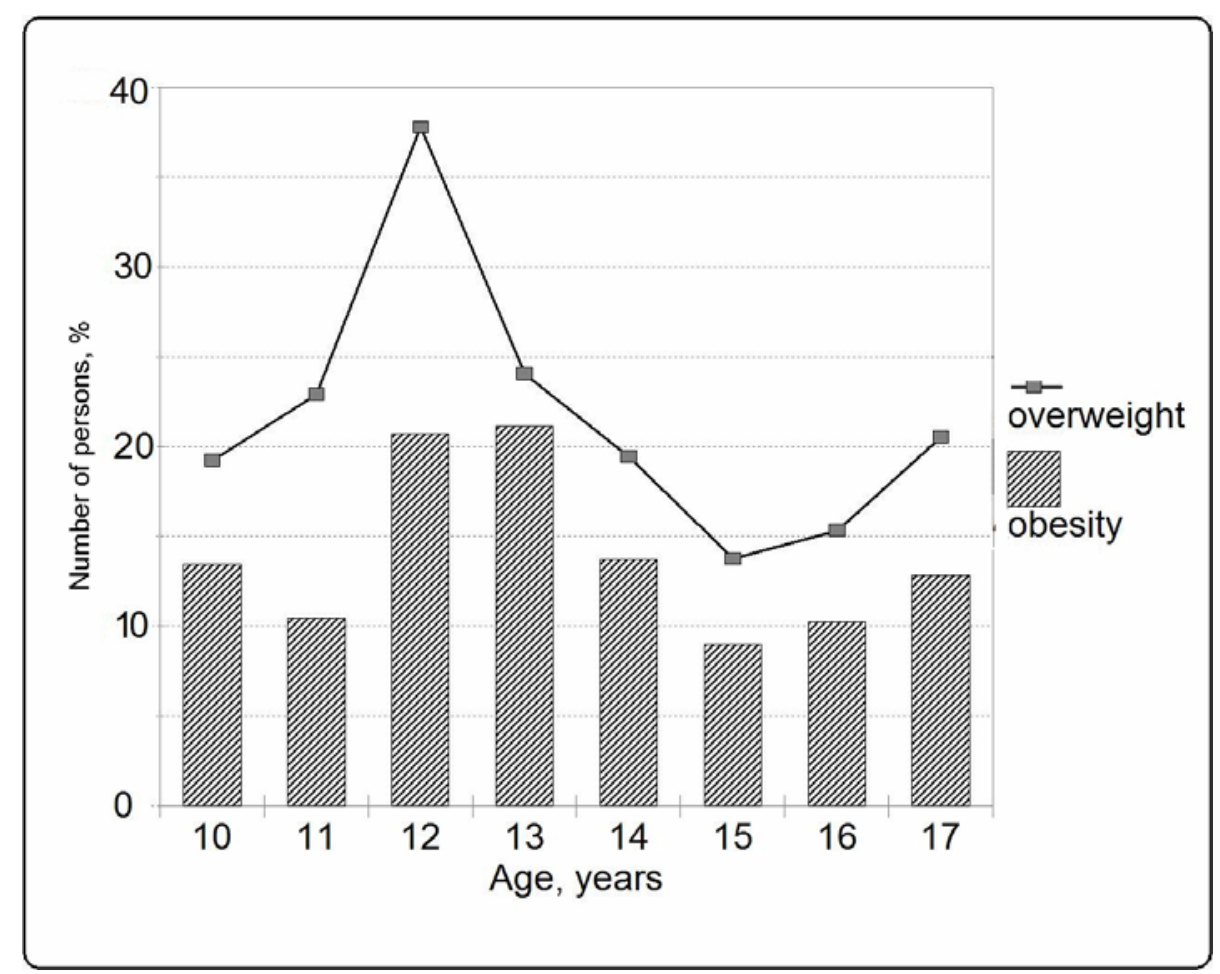

Fig. 2. Age trend in overweight and obesity in surveyed children

nostic and prevention of childhood obesity should take high national priority for health protection.

\section{Conclusion}

1. The prevalence of total overweight in our research is typical for European country and not exceeds $20 \%$ of children population. The prevalence of overweight also varies by age, puberty stage and place of living. The prevalence of obesity is much higher in age 13 years achieving 21,3\%.

2. Special awareness programs to spread healthy messages on good nutrition and health for the prevention of obesity and its consequences need to be initiated.

Prospects of further research. The possible role of obesity risk factors such as nutritional habits, psychological, socioeconomic and familial causes could be studied.

\section{References}

1. Распространенность избыточной массы тела и повышенного артериального давления среди школьников разных регионов Украины / В.Г. Майданник,
М.В. Хайтович, Г.А. Павлишин [и др.] // Междунар. ж. пед., акуш. и гинекол. - 2013. - Т. 3 (1). - С. 33-39.

2. Сорокман Т.В. Антропометричні стандарти та клінічні особливості ожиріння у дітей / Т.В. Сорокман // Міжнар. ендокринол. ж. - 2014. - № 8 (64). - С. 25-28.

3. Effectiveness of a school-based physical activity intervention on obesity in school children: a nonrandomized controlled trial / X. Li, S. Lin, H. Guo [ et al.] // BMC Public Health. - 2014. - № 14. - P. 1282.

4. Emmett P. M. Diet, growth, and obesity development throughout childhood in the Avon longitudinal study of parents and children / P. M. Emmett, L. R. Jones // Nutr. Rev. - 2015. - Vol. 73 (Suppl 3). - P. 175-206.

5. Secular trends in prevalence of overweight and obesity from 2006 to 2009 in urban Asian Indian adolescents aged 14-17 years / D. K. Gupta, P. Shah, A. Misra [et al.] // PLoS One. - 2011. - Vol. 6 (2). - P. e17221.

6. Wang Y. The global childhood obesity epidemic and the association between socio-economic status and childhood obesity / Y. Wang, H. Lim // Int. Rev. Psychiatry. - 2012. - Vol. 24 (3). - P. 176-188.

7. WHO European Childhood Obesity Surveillance Initiative: school nutrition environment and body mass index in primary schools / T. Wijnhoven, J. van Raaij, A. Spinelli [et al.] // Int. J. Envir. Res. Public Health. - 2014. Vol. 11 (11). - P. 11261-11285.

\section{ИЗБЫТОЧНЫЙ ВЕС И ОЖИРЕНИЕ У ДЕТЕЙ ШКОЛЬНОГО ВОЗРАСТА}

\section{Ю.Н. Нечитайло, Н.И. Ковтюк}

Резюме. Детское ожирение стало важной проблемой охраны общественного здоровья. В работе анализируется современный уровень ожирения у детей школьного возраста Черновицкой области. Обследовано 848 детей

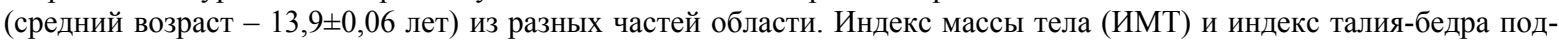
считывались, кроме того определялся Z-индекс ИМТ в соответствии с локальными антропометрическими перцентильными стандартами. Распространенность общей избыточной массы тела составляла 19,9 \%, в том числе ожирение - 13,6\%. Частота избыточной массы изменялась в зависимости от возраста, пола и места проживания. Избыточный вес был у 20,8 \% мальчиков и у 19,2 \% девушек, ожирение, соответственно, у 14,6 \% и 12,3 \%. Частота ожирения была наивысшей в возрасте 12 и 13 лет - более 20\%. Избыточный вес у детей коррелирует с повышением систолического артериального давления $(\mathrm{r}=0,27, \mathrm{p}<0,05)$ и имеет отрицательную взаимосвязь с физической работоспособностью $(\mathrm{r}=-0,21, \mathrm{p}<0,05)$.

Ключевые слова: дети школьного возраста, индекс массы тела, избыточный вес, ожирение 


\section{НАДМІРНА МАСА ТІЛА ТА ОЖИРІННЯ У ДІТЕЙ ШКІЛЬНОГО ВІКУ}

\section{Ю.М. Нечитайло, Н.І. Ковтюк}

Резюме. Дитяче ожиріння стало важливою проблемою охорони суспільного здоров'я. У роботі аналізується сучасний рівень ожиріння у дітей шкільного віку Чернівецької області. Обстежено 848 дітей (середній вік $(13,9 \pm 0,06$ років) з різних частин області. Індекс маси тіла (IMT) та індекс талія-стегна обраховувалися, крім того визначався Z-індекс IMT згідно з локальними антропометричними перцентильними стандартами. Поширеність загальної надлишкової маси тіла становила 19,9 \%, у тому числі ожиріння - 13,6\%. Частота надлишкової маси тіла змінювалася залежно від віку, статі та місця проживання. Надлишкова маса тіла була у 20,8 хлопчиків і в $19,2 \%$ дівчат, ожиріння, відповідно, - у 14,6 \% і 12,3 \%. Частота ожиріння є найвищою у віці 12 та 13 років - більше $20 \%$. Надмірна маса тіла у дітей корелює 3 підвищенням систолічного артеріального тиску $(r=0,27, \mathrm{p}<0,05)$ і має негативний зв'язок з фізичною працездатністю $(\mathrm{r}=-0,21, \mathrm{p}<0,05)$.

Ключові слова: діти шкільного віку, індекс маси тіла, надмірна маса тіла, ожиріння.

Вищий державний навчальний заклад України «Буковинський державний медичний університет» (Чернівці)

Рецензент - проф. С.В. Сокольник

Buk. Med. Herald. - 2016. - Vol. 20, № 3 (79). - P. 132-135

Надійшла до редакції 22.06.2016 року

(C) Y.M. Nechytaylo, N.I. Kovtyuk, 2016 